\title{
O DEBATE FOUCAULT E DERRIDA: razões ou des- razões do pensamento ${ }^{1}$
}

Evando Nascimento

(UFJF)

\section{RESUMO}

Abordagem da polêmica entre Michel Foucault e Jacques Derrida, a propósito da "Primeira Meditação", de René Descartes. São analisados comparativamente os textos respectivos de Foucault, $A$ História da loucura, a "Resposta a Derrida" e "Mon corps, ce papier, ce feu", e de Derrida "Cogito e a história da loucura" e "'Fazer justiça a Freud': a história da loucura na era da psicanálise”.

PALAVRAS-CHAVE: Foucault. Derrida. Descartes. Loucura.

$H o$ ! Ho! É esplêndido ser louco! Charles Dickens, "O Manuscrito de um louco"

O que eles estão fazendo comigo! Jogam-me água fria na cabeça. Não me escutam, não me veem, não me ouvem. O que lhes fiz? Por que me atormentam? O que querem de mim, infelizes? O que lhes posso dar? Nada tenho.

Nikolai Gogol, "O Diário de um louco"

Para Roberto Machado 


\section{Dos fatos}

Em 04 de março de 1963, Jacques Derrida pronuncia no Collège Philosophique em Paris a conferência "Cogito et Histoire de la folie", cujo texto foi inicialmente publicado na Revue de Métaphysique et de Morale e posteriormente retomado em L'Écriture et la différence, livro de $1967 .{ }^{2}$ Esse ensaio contém duas críticas fundamentais ao livro de 1961 de Michel Foucault, L'Histoire de la folie à l'âge classique:" 1- numa primeira parte, são colocadas questões metodológicas e epistemológicas acerca da "própria história da loucura" e de toda a rede conceitual aí implicada; 2- numa segunda parte, questionam-se três páginas de abertura do segundo capítulo, "Le Grand renfermement" ("O Grande enclausuramento"), em que Foucault comenta o texto da primeira das Méditations métaphysiques, de Descartes, demonstrando como, no pórtico desse livro fundamental, dá-se a exclusão do louco e da loucura, antes mesmo de comparecer a experiência de dúvida do Cogito. Para Foucault, a "Primeira Meditação" seria, portanto, o momento exemplar do grande internamento dos loucos, próprio à idade dita clássica, ou seja, o século XVII. Para Derrida, a exclusão não só não ocorre na abertura do livro de Descartes como todo o instante da dúvida que levará à afirmação do Cogito cartesiano implica uma cena de loucura, ou melhor, de "extravagância". Como narra o biógrafo de Derrida, ${ }^{4}$ Foucault teria reagido bem à palestra, a que assistiu a convite de seu antigo discípulo, chegando até a felicitá-lo; todavia, mudará de ideia no início dos anos 1970, quando Derrida deixou de ser um jovem brilhante e promissor para se tornar o reconhecido autor de grandes textos.

Duas cartas de Foucault daquele período atestam a admiração que ele sentia pelo trabalho de seu ex-discípulo. Uma primeira data de 27 de janeiro de 1963 e diz respeito ao modo como ele recebe a tradução e a introdução à Origem da geometria, de Husserl. A segunda, datada de 11 de março de 1963, é uma resposta de Foucault à conferência pronunciada por Derrida uma semana antes no Colégio Filosófico, e demonstra como a primeira recepção à leitura contundente de seu livro foi extremamente positiva, concluindo com um apelo à amizade entre os dois. Cito um trecho da carta para flagrar a primeira impressão foucaultiana:

Naquele dia, como você pode imaginar, não pude lhe agradecer como gostaria: não tanto ou não apenas pelo que disse de demasiado indulgente a meu respeito, mas pela enorme e maravilhosa atenção que me 
dispensou. Me impressionou - a ponto de na hora ficar desconcertado e bastante desajeitado no que consegui dizer - a justeza de suas palavras, que foram, sem embaraço, ao fundo do que desejaria ter feito, e até mais além. Decerto não tratei com o devido cuidado a relação entre o Cogito e a loucura em minha tese: por meio de Bataille e de Nietzsche, voltava a ela com lentidão e por inúmeros desvios. Você mostrou sobejamente o caminho mais direto: e pode compreender perfeitamente porque lhe devo o mais profundo agradecimento.

Teria um prazer infinito em revê-lo. [...] Peço que acredite na amizade deveras profunda e fiel que lhe dedico. ${ }^{5}$

Quase uma década depois, o tom agradecido e amical vai mudar radicalmente. Em 1972, o diretor de uma revista japonesa submete a Foucault o plano de um número dedicado a seu trabalho, um "dossiê Foucault", que contaria com textos seus, com o ensaio de Derrida sobre a História da loucura, além do ensaio de um especialista japonês sobre o "discurso de Foucault" e a "escritura de Derrida". Foucault resolve então incluir um inédito nesse plano, sua violenta "Resposta a Derrida". ${ }^{6}$ Não satisfeito, ele escreve uma versão ampliada do artigo, que virá, no mesmo ano de 1972, como anexo da nova edição de Histoire de la folie, ${ }^{7}$ pela Gallimard, a qual ele remeterá a Derrida com uma dedicatória não desprovida de ironia. A partir daí, o antigo mestre e o ex-discípulo se tornam desafetos, apenas se reencontrando no episódio de 1982 em que Derrida é preso pelo regime comunista de Praga, sob falsas acusações de tráfico de droga, e em seguida liberado. Foucault não só denunciou o episódio no rádio, como convidou Derrida para um jantar em sua casa após a liberação. Porém, até a morte de Foucault em 1984, a amizade jamais será integralmente refeita. Curiosamente, Foucault retira em 1972 o prefácio da primeira edição do livro, o qual tinha sido utilizado por Derrida em sua argumentação altamente desconstrutora; igualmente, a resposta a Derrida será mais tarde removida dos anexos.

Em 1991, participando de um evento sobre os trinta anos da História da loucura, a convite dos psicanalistas René Major e Elisabeth Roudinesco, Derrida volta a falar de Foucault, em particular de seu grande livro. Dessa vez, no entanto, em “'Fazer justiça a Freud”: a história da loucura na era da psicanálise", ele declara que, a despeito das solicitações nesse sentido, não reabrirá o debate, entre outros motivos porque Foucault está morto; prefere então falar não mais da relação do pensamento foucaultiano para com Descartes mas para com Freud. No entanto, nes- 
se texto publicado no livro do evento e retomado em Résistances: de la psychanalyse,${ }^{8}$ Derrida não resiste a aludir à antiga discussão em diversos momentos de sua argumentação. Na verdade, a retoma sucintamente, por meio dos comentários sobre a relação Foucault/Freud.

Diante da impossibilidade de dar conta, em tão poucas páginas, da complexidade do debate entre os dois pensadores, farei aqui apenas um recorte interpretativo, visando a um futuro desenvolvimento do tema. Proponho, portanto, menos uma análise detalhada de todo o grande dossiê envolvido na discussão do que o risco interpretativo de quem tenta observar, a certa distância, a força de dois pensamentos muito próximos, porém igualmente muito distintos em suas estratégias, argumentações e efeitos.

\section{Das interpretações}

O risco de toda verdadeira interpretação, ensina-nos Foucault em seu célebre ensaio "Nietzsche, a genealogia, a história", é a "destruição do sujeito de conhecimento pela injustiça própria da vontade de saber. $\mathrm{O}$ verdadeiro intérprete brinca com o fogo, que, ao mesmo tempo e segundo o paradigma iluminista, dá a luz da razão, mas também pode trazer a destruição de quem o manipula. A história de Prometeu constitui o mito originário, que associa a luz da razão à eterna loucura do sofrimento. Interpretar é arriscar-se por caminhos não trilhados, sem saber exatamente aonde vão dar. E não há pensamento (tudo o que me interessa, aqui e sempre) sem interpretação, menos ainda sem avaliação em sentido nietzschiano. Ali onde algum sentido precisa ser proposto para que outros sejam deslocados, onde valores devem ser articulados para que outros sejam subtraídos, nesse intervalo entre duas interpretações não necessariamente opostas, mas obrigatoriamente distintas, toda uma época pode transcorrer. Assim, atualmente talvez estejamos vivendo a época da pós-razão ocidental em sua plenitude, o que não significa em absoluto o advento da plena desrazão... ${ }^{10}$

Assim, como dito, no início dos anos 1960, dois pensadores franceses, entre os mais influentes na segunda metade do século XX e ainda agora no século XXI, propuseram interpretações bem distintas para certa passagem das Meditações de Descartes. Não se trata aqui de tomar partido nessa titanomaquia, pois nem de longe nutro o desejo de arbitrar uma luta entre titãs, cujas forças particulares o século atual se incumbe de mensurar. Nenhum desejo, pois, de tirar a razão desse para dar razão àquele outro - isso seria uma verdadeira loucura. Importa, sobremodo, 
surpreender em cada fala uma estratégia mínima de deslocamento da reflexão do outro, a fim de dar vez e lugar a sua própria elocução. Nisso, estão em jogo dois modos distintos de abordar, expor e fazer funcionar os dispositivos dessa velho-nova instituição chamada filosofia.

Em Foucault, como se sabe, os gestos de um historiador bastante especial recobrem as feições do filósofo, desde o título da obra seminal História da loucura na idade clássica. Já em Derrida, se a argumentação se aproxima bastante da retórica filosófica, a ponto de mimetizá-la de forma vertiginosa, a ambição, como também se sabe, é ir além das determinações tradicionais da filosofia, ou, como se dizia até há bem pouco tempo, da "tradição metafísica". Com isso, sinalizo desde já que, para nenhum dos dois, a discussão em torno das Meditações de Descartes significou apenas mais um capítulo na longa tradição de questionamento filosófico. Seja tomando a história como contrapartida (no caso de Foucault), seja intentando um gesto de desconstrução (no caso de Derrida), não se tratou de "superar" a filosofia enquanto discurso, mas sim certamente de abalar alguns dos fundamentos da filosofia enquanto instituição, com reflexos no solo da cultura, tendo como momento exemplar a fundação do Cogito cartesiano. Sabendo-se, todavia, que não há instituição sem discurso; ao contrário, os fundamentos institucionais se compõem de elementos discursivos e não discursivos, em outros termos, de letra e de silêncio, de texto e de gestos figurais, de documento e de monumento, entre outros fatores. E é justamente no intervalo entre a palavra e o mutismo, se quiserem, entre a razão e seus outros (silêncio, morte, loucura, demência, enfermidade, "arte" etc.) que tentarei me deslocar. Menos com a finalidade de atingir certo alvo do que pelo desejo de expor algumas das fissuras, dos avanços e dos recuos, dos desdobramentos em suma, de um debate intelectual no fundo bem francês. ${ }^{11}$

\section{Foucault entre razão e loucura}

Todo o esforço inicial desse livro-acontecimento que é História da loucura na idade clássica, se faz no sentido de entender o que se passa entre o final da Idade Média e o advento do que na França se chama de Idade Clássica ou de era dos grandes racionalismos, quer dizer, o século XVII. Se na Idade Média, a lepra constituiu o grande inimigo a ser encerrado nos leprosários para o bem da comunidade, com o final de tal período esses centros de reclusão perderão sua função, até o advento de um inimigo tão ou mais poderoso, a loucura, que ameaça a razão como um 
rival externo e insidioso. Todavia, antes que a loucura se configure como o perigo a ser encerrado atrás de grossos portões, há uma espécie de convivência ou ao menos de tolerância em relação aos ditos loucos por parte dos que assim não se consideram. A stultifera navis, a nau dos loucos, representou o lugar de uma ameaça ainda de algum modo volante, por assim dizer à deriva - ameaçadora mas ainda suficientemente isolada do convívio normal entre os homens para não ser objeto de franca exclusão.

Já o período barroco, o do século XVI, faixa temporal situada entre a alta Renascença e os primórdios da referida Idade Clássica, encenará os jogos reversíveis entre razão e loucura. ${ }^{12}$ Para Foucault, durante o Barroco, cuja expressão máxima seriam o Dom Quixote de Cervantes e as peças de Shakespeare, haveria uma forte reversibilidade entre os opostos, a saber: um fundamento racional da loucura (certamente por ela dispor também de suas razões) e um grão de loucura em toda razão. É essa contaminação dos contrários que aparece como dúvida dos ensaios de Montaigne; nestes, o pensamento não pode excluir de todo certa camada de delírio e de alucinação. Diz Foucault: "Talvez aí esteja o segredo de sua múltipla presença na literatura no final do século XVI e no início do século XVII, uma arte que, em seu esforço para dominar essa razão que se busca, reconhece a presença da loucura, de sua loucura, a circunscreve, investindo-a, para finalmente triunfar sobre ela. Jogos de uma idade barroca". ${ }^{13}$

Por uma natureza completamente distinta vai ser marcada a obra-mestra do pensamento racionalista que sucederá o Barroco, as Méditations métaphysiques, de Descartes, em que se afirma a teoria do Cogito, a qual delimitará o início de uma nova era da história ocidental, de modo tão intenso que acabará, para muitos, por se identificar como a essência mesma dessa civilização de origem europeia. Se, como acabei de expor, segundo Foucault, em Montaigne, a razão dita normal não consegue excluir aquilo que a coloca em perigo, para Descartes, o jogo decisivo se fará a partir do ponto em que o instante da dúvida não admite comércio (para utilizar uma expressão shakespeariana) com a loucura. Enquanto sonhos e ilusões precisam ser estruturalmente superados a fim de se atingir o estágio do pensamento puro, ser ou estar louco não é admissível como possibilidade estrutural para a boa realização da tarefa de duvidar com a finalidade de atingir a certeza cartesiana. Sonhos e ilusões são funções normais do pensamento (todos nós cotidianamente sonhamos e nos iludimos um pouco), enquanto a loucura nem de longe tem o direito de 
residência, ainda que momentânea, na cidadela da razão. Diz lapidarmente Foucault, interpretando a primeira das Meditações de Descartes:

$\mathrm{Na}$ economia da dúvida, ocorre um desequilíbrio fundamental entre loucura, de um lado, sonho e erro, do outro. A situação desses fatores é diferente em relação à verdade e àquele que a busca; sonhos e ilusões são superados na estrutura mesma da verdade; mas a loucura é excluída pelo sujeito que duvida. ${ }^{14}$

O instante da dúvida, que funda o Cogito cartesiano, significa igualmente o momento fundador de uma razão identificada a si própria, a qual apenas aceita as formas do pensamento que ela pode domesticar e reduzir, como etapas do negativo a serem estruturalmente superadas. O outro, que os sonhos, as ilusões e os erros configuram, apenas serve para representar uma razão finalmente depurada de todo excesso, de toda fissura, em suma, de toda "loucura", ao contrário do homem barroco, que ainda se representava confusamente um pouco como "meio louco". Para Foucault, a ratio ocidental se afirmará duplamente pela exclusão daquilo que nada tem a ver com sua natureza mais própria (seu princípio de razão, sua racionalidade essencial), quer dizer, a loucura, e por uma superação estrutural do que nela não pode ser obliterado, mas apenas de algum modo redimido, quer dizer, as fantasias dos sonhos e do humano engano.

O encaminhamento da dúvida cartesiana parece testemunhar como, no século XVII, o perigo se encontra conjurado e como a loucura é colocada fora do domínio de pertença, no qual o sujeito detém seus direitos à verdade: esse domínio que, para o pensamento clássico, é a própria razão. Doravante a loucura está exilada. Se o homem sempre pode ser louco, o pensamento, como exercício da soberania de um sujeito que se impõe o dever de perceber o verdadeiro, não pode ser insensato. É traçada uma linha divisória que logo vai tornar impossível a experiência tão familiar ao Renascimento de uma Razão desrazoável, de uma razoável Desrazão. Entre Montaigne e Descartes, um acontecimento se deu: algo que diz respeito ao advento de uma ratio. ${ }^{15}$

Isso não quer dizer que a loucura se anulou de todo nessa cena de exclusão cartesiana. Para Foucault, se a desrazão foi enterrada nesse solo, aí desaparecendo, aí também ganhou raízes. E é esse enraizamento da loucura no solo da razão, como seu duplo excluído, que o livro - o qual faz parte com grande legitimidade da própria história do Ocidente, pondo-a radicalmente em questão -, passa a elucidar. 


\section{Derrida e a extravagância do Cogito}

Acabei de enunciar, a partir do livro de Foucault, um dos pontos fundamentais da argumentação de Derrida: será que a desejada "arqueologia do silêncio" - anunciada desde o primeiro prefácio de História da loucura $^{16}$-, aquela que daria voz à loucura silenciada, não é ainda da ordem da razão que se quer questionar? Em outras palavras, a arqueo-logia, proposta por Foucault, deteria ainda uma lógica, inscrevendo-se, portanto, numa história do sentido, ou na História simplesmente, visto que toda história é, de certo modo, uma história teleológica do sentido. ${ }^{17}$ A pretensão de Foucault em fazer uma história da própria loucura seria ela mesma "louca", na medida em que qualquer história supõe uma organização e uma linearidade, ou seja, uma ordem racional, a qual, dentro da lógica do discurso foucaultiano, teria sido responsável pelo silenciamento da loucura. O alogos da loucura seria, desse modo, circunscrito e encerrado pelo lógos do historiador-filósofo. O problema se torna então circular: como fazer uma história da loucura que não corresponda no fundo a mais uma racionalização (quer dizer, a um rebaixamento e a um silenciamento) daquilo que supostamente a razão excluiu no instante mesmo de fundação do racionalismo clássico? Afirma Foucault acerca da história que propõe sobre a "estrutura da experiência da loucura": "Isso significa que não se trata de modo algum de uma história do conhecimento, mas dos movimentos rudimentares de uma experiência. História não da psiquiatria, mas da própria loucura [mais de la folie elle-même], em sua vivacidade, antes de qualquer captura pelo saber". Entretanto, o próprio Foucault não deixa de perceber a quase impossibilidade de seu projeto, todavia sem tirar todas as consequências disso: "A liberdade da loucura só é entendida do alto da fortaleza que a detém prisioneira". ${ }^{18}$

A questão a que Derrida retorna, em “'Fazer justiça Freud': a história da loucura na era da psicanálise", em 1991, é a da possibilidade mesma de uma história da loucura. ${ }^{19}$ Seria a loucura objetificável sem perder sua natureza mais própria? Será que ao dar um sentido ao que escapa ao horizonte do sentido não se está sobredeterminando de modo hiperracional aquilo que pretensamente deveria se subtrair aos ditames da razão? Em outras palavras, o projeto em si de uma história da loucura parece inevitavelmente reconduzir à ordem racional de que o pensamento de Foucault tenta no mínimo escapar. E não me parece que a solução seria cair num discurso irracionalista, a que Foucault sempre se subtraiu, a 
despeito das muitas acusações em contrário por parte de seus detratores, mas de repensar os fundamentos da própria história como conduzida pelo princípio de razão. $\mathrm{O}$ aprimoramento posterior do método genealógico-arqueológico implicará vários passos nessa direção.

$\mathrm{Na}$ impossibilidade de resumir todos os argumentos de Derrida a propósito da História da loucura, vou me ater à segunda parte de sua reflexão, aquela que diz respeito à leitura de Foucault da "Primeira Meditação" cartesiana; mas a primeira parte estará não só pressuposta mas também será aludida em mais de um momento. Para Derrida, haveria nessa leitura dois equívocos de base: 1) Descartes não se preocupa em nenhum momento com a loucura em si mesma, mas apenas a trata como referência lateral para sua sequência de raciocínios; 2) a loucura - ou como Derrida prefere a extravagância - sublinhada por Foucault nunca é de todo descartada, ao contrário, retorna num ponto crucial para Descartes estabelecer em que a dúvida deixa de ser o fundamento absoluto da existência.

Segundo Derrida, para Descartes atingir o ponto essencial em que a dúvida deixa de existir, afirmando-se a existência no Cogito, é preciso passar pela extravagância de uma hipérbole em que o sujeito da meditação finge acreditar que tudo o que seus sentidos percebem é falso. Trata-se de um recurso de fingimento, de uma ficção lógica, no fundo bastante "louca”, para atingir num segundo momento a racionalidade máxima. Como $s e$ - expressão idiomática que é o fundamento de toda ficção - como se fosse preciso fingir-se de louco, fingir que está sendo o tempo todo enganado por um gênio mau, para se livrar das limitações do sensível. Tal seria a famosa fábula do Malin Génie.

Se na literatura de Charles Dickens, como visto na epígrafe deste ensaio, o louco se regozija de sua loucura, por uma pura ficção, a fim de que adentremos o raciocínio labiríntico de um suposto insano - na ficção cartesiana, para Derrida, a loucura só é menor porque tem a finalidade de atingir a zona da razão absoluta, atravessando o seu contrário para encontrar finalmente um eixo. Se, igualmente, Hamlet fingindo-se de louco acaba de fato louco por toda a desrazão que reina na Dinamarca, o personagem de Descartes (o "eu" do cogito que diz "eu penso, eu sou"), o qual finge ser enganado pelo gênio mau, sobrevive pelo fio que o conduz para fora do labirinto da loucura: o próprio pensamento. Cito Descartes: "Suponho, portanto, que todas as coisas que vejo são falsas; persuado-me de que nada jamais houve de tudo o que minha memória preenche com mentiras me representa; creio que o corpo, a figura, a extensão, o movi- 
mento e o lugar não passam de ficções de meu espírito. O que, portanto, poderá ser estimado como verdadeiro? Talvez nada além de que nada há no mundo de certo". ${ }^{20}$ Descartes finge então que nada é confiável, sobretudo aquilo que habita sua própria mente, seu espírito. Trata-se de pura mímesis filosófica, numa cena essencialmente fictícia para atingir a pura racionalidade.

Se o louco é o insensato por excelência, tal ocorre porque a redução fenomenológica da loucura e de tudo o que, no mundo e fora dele, assume as vestes do negativo funciona em nome do sentido. Insensato remete literalmente a sem-sentido, a não sentido, a nonsense. A crítica de Derrida se dirige menos ao apontamento do reducionismo racionalista em si proposto por Foucault do que ao momento em que a redução e o rebaixamento da loucura ocorrem e tudo o que daí advém. Para Derrida, o momento hiperbólico do Cogito, ou seja, a cena do fingimento, é necessariamente extravagante e louco, mais louco até do que a loucura dita normal, aquela do assim chamado doente mental no código da psiquiatria. $\mathrm{O}$ erro de Foucault teria sido apontar desde a "Primeira meditação" o banimento da loucura do seio da cidadela filosófica. O instante do Cogito como afirmador da existência é acompanhado pelo mau gênio responsável pela loucura, ou antes, constitui a etapa que precede a separação entre razão e loucura, entre senso e não senso, entre consciência e delírio, entre a razão e seus contrários. Diz Derrida: “Quer eu seja louco ou não, Cogito, sum. Em todos os sentidos dessa palavra, a loucura é somente um caso do pensamento (no pensamento). Trata-se então de recuar para um ponto em que toda contradição determinada na forma de tal estrutura histórica de fato pode aparecer, aparecendo como relativa a esse ponto-zero, no qual o sentido e o não sentido determinados se juntam em sua origem comum". ${ }^{21}$

Para Derrida, a extravagância fingida ainda seria um momento fundamental da experiência do Cogito como indeterminação entre loucura e desrazão; depois então é que a infinitude divina viria afirmar um lógos identificado a si mesmo, excludente em relação a tudo o que lhe seja contrário. Se o lógos é o discurso em geral e o discurso por excelência da filosofia, ele vem silenciar aquilo que, por si mesmo, está prometido ao silêncio, à morte, à aniquilação, ou seja, a insensatez daquele que não é capaz de obra: o louco simplesmente. Foucault define e repete a definição da loucura como ausência de obra, desde o prefácio de História da loucura: "O que é então a loucura, em sua forma mais geral e mais concreta, para quem recusa desde logo todas as dominações do saber sobre ela? Decerto nada além da ausência de obra". ${ }^{22}$ 
Trata-se, portanto, de duas "analíticas da finitude" do pensamento cartesiano, dois modos de marcar a experiência radical de um Cogito em sua relação com a loucura. Para Derrida, a loucura do louco é menos relevante do que a extravagância de um pensamento que precede a oposição entre razão e desrazão. Para Foucault, tal como ele já tinha exposto nas três páginas iniciais do capítulo sobre o grande enclausuramento, a loucura e sua perturbadora experiência estão excluídas de antemão por um sujeito que medita e controla cada passo de sua meditação. E quando a loucura retorna, a título de exemplo, é porque já foi previamente separada, discriminada, desqualificada ("Mas o quê? São loucos"23) por uma razão que propõe o exercício da dúvida a partir de um solo de certeza, deslegitimando aquilo que poderia abalar o fio condutor da meditação. Sonho e erro são, segundo Foucault, possibilidades de um sujeito meditativo, que os tem continuamente ao alcance da mão, por mais bizarros que pareçam ser. Já a loucura é "privilégio" de poucos; não é louco quem quer e no momento em que deseja - para isso, é preciso ter o cérebro perturbado por fatores de que um sujeito normal não sofre. O louco, por assim dizer, se exclui por si mesmo, por sua incapacidade de estabelecer os limites entre realidade e delírio. Já o sonhador dito normal embaralha tais limites, mas sabe que eles existem; a experiência de sonhar não deixando de ser provisória e perempta em relação ao momento das ideias claras e distintas.

Em sua resposta a Derrida, Foucault reafirma e desenvolve o argumento da exclusão da loucura por Descartes na Primeira Meditação. Um de seus argumentos básicos consiste no fato de Derrida não recorrer ao original latino, em que à palavra francesa fou (louco) correspondem dois termos diferentes insanus e amens ou demens. O demens é avaliado do ponto de vista jurídico, como o incapaz de responder por seus próprios atos, enquanto insanus designa o louco em sentido não especializado, próximo do senso-comum: aquele que se entrega a seus delírios imaginativos. Para Foucault, no texto cartesiano a passagem do insanus ao demens reforça a impossibilidade de o louco, ao contrário do sonhador, poder fazer parte do processo meditativo da dúvida, depois do qual se atinge a certeza. ${ }^{24}$

Sébastien Buckinx, que escreveu um longo trabalho sobre a polêmica, intitulado Descartes entre Foucault e Derrida: la folie dans la Première méditation, considera ser difícil dar razão exclusivamente a um ou a outro. Analisando amplamente o conjunto de textos de Descartes relacionados à Primeira meditação, o especialista belga consegue indiciar 
acertos e falhas em ambas as leituras. Depois de apontar, por meio de três postulados, como Derrida e Foucault são devedores de comentários clássicos sobre o corpus de Descartes, Buckinx afirma:

Se a análise do debate entre Foucault e Derrida em torno do "argumento da loucura" conduz à revelação de tais postulados, estes testemunham - mais além da originalidade do comentário de cada um - a respeito da dívida dos dois filósofos para com os comentários clássicos da primeira meditação. Todavia, se tais elementos devem ser novamente postos em causa, antes de qualquer explicitação da originalidade das Meditações em relação aos outros textos de Descartes, expondo suas razões, então escolher quem dos dois, se Foucault ou Derrida, sai vencedor desse "debate sobre a loucura" se revela supérfluo. A leitura de um depende da do outro, e juntas abrem a porta para uma releitura do texto cartesiano debatido. ${ }^{25}$

\section{Fingimento e loucura}

Se a análise de Foucault em alguns pontos parece ser mais fiel à letra do texto de Descartes, a experiência descrita por Derrida não deixa de ser menos pertinente e fascinante para entender talvez não a loucura em si, a "própria loucura", como diria Foucault, mas certa alucinação que ocorre quando alguém decide elaborar uma ficção, seja ela teórica ou literária. Sobretudo quando tal ficção desenvolve a fala de alguém que supostamente está louco.

Cabe neste ponto um esclarecimento: toda a questão hoje seria não mais substancializar a loucura como um conceito ("a própria loucura"), mas perceber, com e mais além de Foucault, a precariedade dessa designação, que ainda apontaria para um objeto ou sujeito plenamente identificável na realidade. O que se chama de loucura ou de louco são diversas síndromes e formas de sofrimento, que passaram por inúmeras revisões nas últimas décadas. Sublinho também a diferença entre o "portador de loucura", no plano do real, e a loucura como metáfora para pensar de modo inovador certas questões da filosofia e da literatura. Como não tenho nenhuma pretensão de ser psiquiatra nem psicanalista, menos ainda historiador das mentalidades, o que me interessa de fato são a loucura e suas metáforas.

O comentário de Joyce acerca do Ulysses, que serve como epígrafe ao ensaio de Derrida, ajuda a pensar as relações entre ficção e loucura: "Pouco importa, esse livro foi totalmente arriscado. Uma folha transparente o separa da loucura". ${ }^{26}$ Nunca é desprovida de certa insensatez e 
mesmo de "insanidade" a experiência de pôr-se na pele de um outro ou de uma outra, sejam esses tais personagens e/ou narradores. Mas quando tais personagens-narradores são declaradamente loucos, como é o caso das duas ficções citadas de Charles Dickens e de Nikolai Gogol em epígrafe, respectivamente "O Diário de um louco" e "O Manuscrito de um louco", ${ }^{27}$ a insanidade atinge uma alta potência, pois encena a loucura que acontece diante de nossos olhos. A loucura, por assim dizer, entra de fato e de direito em cena, representando o sofrimento trágico de um sujeito que sucumbe a seu próprio modo de experimentar e conhecer o mundo. Tal como certo filósofo alemão, que teria desabado diante do episódio de um cavalo sendo açoitado nas ruas de Turim (Nietzsche).

Pode-se argumentar, contra Derrida e a favor de Foucault, que o momento extravagante do Cogito nas Meditações não passa de figura de retórica, uma mera "ficção" visando a afirmar o que realmente importa, a ordem racional que exclui tudo o que lhe é dessemelhante. Mas seria acreditar muito pouco no poder das ficções, mesmo as mais retóricas, de agenciar forças díspares, de encenar aquilo que precede as grandes divisões, as grandes decisões, os grandes confinamentos, como defende Derrida. Se, para funcionar como discurso e como instituição, a filosofia, ou ao menos um tipo de filosofia racionalista, precisou se aliciar à ordem que bane ou confina o louco da cidade numa camisola e num asilo, isso significa que em algum momento o pensamento filosófico, para ser pensamento e não simples enunciação escolástica, precisou atravessar a experiência da alteridade. É esse o argumento sustentado de ponta a ponta por Derrida: o cartesianismo não exclui desde o limiar o não sentido, a loucura e a morte, pois precisa deles para se autoafirmar. Antes de se firmar como discurso das ideias claras e distintas, é capital aceitar e encenar o momento em que o demônio, o Gênio Mau, parece viger no mundo; tal como diria o protagonista de Grande sertão: veredas: o diabo está em toda parte. Para bem excluir o outro, é preciso experimentá-lo, conhecê-lo por dentro, como um inimigo íntimo, até chegar ao ponto em que o nó se desate e a razão absoluta se confirme em nome da verdade divina, instaurando enfim o reino de uma ratio onipresente, onisciente mas profundamente redutora, finita em sua potência.

O que está em jogo em toda essa discussão é um momento fundamental da história do Ocidente e do conceito teleológico de história, a partir dos quais interpretações para a inquietante alteridade serão dadas, rebaixando tudo o que não é espelho para a consciência e para o raciocínio puro. Resume Derrida: 
Motivo pelo qual o ato do Cogito, no instante hiperbólico em que se mede à loucura, ou antes, se deixa medir por ela, esse ato deve ser repetido e distinguido da linguagem ou do sistema dedutivo no qual Descartes tem que inscrevê-lo a partir do momento em que o propõe à inteligibilidade e à comunicação, ou seja, a partir do momento em que ele o reflete para o outro, o que significa para si. É nessa relação com o outro como outro de si que o sentido se tranquiliza contra a loucura e o não sentido... E a filosofia é talvez essa precaução tomada bem próximo da loucura contra a angústia de ser louco. ${ }^{28}$

Nisso, razão, filosofia e discurso histórico assumem a máxima complexidade e uma das dificuldades de fazer uma história da loucura "por ela própria", como gostaria Foucault, é que não há lógos no Ocidente que não exclua o seu contrário (talvez esta seja a definição mesma do que há alguns séculos se chama de "Ocidente": o poder de rebaixar e excluir a alteridade, por bem e mal), ainda mais quando o que se chama de louco se identifica para nós ao silêncio e à ausência de Obra. Como sintetiza Marc Goldschmit, num estudo bastante curto, mas convergente com a leitura que proponho: 'É essa 'raiz comum' da Razão e da Loucura que Derrida tenta pensar quando mostra que o cogito vale mesmo se estou louco: aquém ou além da razão e da loucura historicamente constituídas, há a Razão e a Loucura ainda indivisas e inseparáveis". ${ }^{29}$

Se o louco fala, sendo muitas vezes tagarela, sua fala ainda não seria uma obra, mas apenas um murmúrio gritado em busca do sentido, sentido este que lhe seria negado pela ordem racional. Na ordem da cidade, nem todo mundo faz ou produz sentido; para tanto, é preciso ter as ideias distintas e claras, dispondo do poder argumentativo e da convicção do Cogito identificado a si mesmo, axial e controlador das diferenças. Nada mais incômodo, nesse sentido, do que um discurso delirante, do que uma fala sem eixo nem direção ou sentido vetorial. Para ser ouvido, é preciso que o sujeito do discurso fale em alto e bom som, explicitando a que veio, como veio, com que finalidade. Basta faltar o objetivo para que o discurso seja considerado louco, sem pé nem cabeça, desordenado, segundo os parâmetros da decisão racional.

Motivo pelo qual cabe à arte fingir dar voz ao que não tem vez na república filosófica, como fizeram os loucos geniais Dickens e Gogol, com seus dilacerantes diários e manuscritos da loucura fingidamente por ela própria.$^{30} \mathrm{Na}$ ficção, na literatura e na arte, não basta ser louco, cabe também saber fingir-se de louco, assumindo a extravagância de entrar 
na pele do outro ou da outra, para veicular essa fala incoerente que tanto incomoda, ontem no século XVII, bem como no momento atual.

No fundo, continuamos muito cartesianos e pós-cartesianos, internando e encerrando os loucos em suas camisolas, cobrindo o que não é espelho para uma consciência autorrefletida. Ainda não sabemos o que fazer com o diferente, o silencioso e o balbuciante a não ser, depois de cinco décadas da publicação do grande livro de Foucault, reduzi-lo a um saber clínico e/ou crítico, raramente transformando-o em potência criadora e crítica do viver dito normal. Potência efetivamente crítica dessa capa de normalidade que basta levantar uma de suas pontas para se mostrar o seu contrário: a incerteza, a indeterminação e a morte. A ordem do discurso viria silenciar ainda mais o já silenciado, calar o que não tem voz, encarcerar a loucura em sua própria falta de lógica, o que, para a própria ordem normal e normativa, seria um atestado de óbito em vida, pois perde assim a dimensão trágica de suas origens. Nisso bem concordam o mestre Foucault e seu antigo discípulo Derrida, o qual um dia ousou levantar a voz para discordar da fala magistral.

Nessa perspectiva, tudo o que me interessa nesses pensadores excede a letra de suas discussões: um certo além da objetividade discursiva (paradoxalmente denunciada por ambos), que anuncia um demonismo e um satanismo tampouco objetiváveis pela dogmática cristã. $\mathrm{O}$ excesso não é a transgressão, que, segundo Bataille, apenas faz confirmar a norma. ${ }^{31}$ Ao contrário, o excesso é um traço que se inscreve no corpo normativo tanto apontando seus limites (por natureza, não há norma sem delimitação histórica, social, cultural etc.), quanto o que vai além desses limites, dessas fronteiras, desses territórios demarcados. Sob esse ângulo, não há nem apocalipse (transgressivo) nem integração (redutora), mas um pensamento do limite, que tanto se situa na borda quanto a ultrapassa espaço-temporalmente. $\mathrm{O}$ excesso excede nas fronteiras do território demarcado, abrindo o horizonte para o que não se subsume ao mesmo e antecipando o advento de certo não saber, sem escatologismo messiânico, todavia.

Não haveria, portanto, pensamento sem fundo de "loucura", mas a historicidade da filosofia racionalista se faria - porém isso não seria seu apanágio - como projeto para calar aquilo que é o cerne e o motor de sua atividade, qual seja, a luz obscura da cegueira, da morte, do não ser e do não sentido; em suma, do que ainda hoje candidamente chamamos de "loucura". 


\section{REASONS OR UNREASONS OF THOUGHT}

\section{ABSTRACT}

Approach on Foucault-Derrida polemic about the "First meditation" by René Descartes. We will analyse the following texts: History of madness, "Reply to Derrida" and "My Body, this paper, this fire", by Foucault ; "Cogito and the History of madness" and "To do Justice to Freud: The History of madness in the age of psychoanalysis", by Derrida.

KEYWORDS: Foucault. Derrida. Descartes. Madness.

\section{REFERÊNCIAS}

BATAILLE, Georges. L'érotisme. Paris: Minuit, 1992 [1957].

BUCKINX, Sébastien. Descartes entre Foucault e Derrida: Paris: L'Harmattan, 2008.

DESCARTES, René. Méditations métaphysiques. Paris: Gallimard, 1992.

DERRIDA, Jacques. Cogito et l'histoire de la folie. In: . L'écriture et la différance. Paris: Seuil, 1967, p. 51-97.

DERRIDA, Jacques. "Être juste avec Freud": l'histoire de la folie à l'âge de la psychanalyse. In: . Résistances: de la psychanalyse. Paris: Galilée, 1996, p. $89-146$.

FOUCAULT, Michel. Histoire de la folie à l'âge classique. Paris: Gallimard, 1995 [1961].

FOUCAULT, Michel. Mon corps, ce papier, ce feu. In: Dits et écrits II: 1970-1975. Paris: Gallimard, 1994a, p. 245-268.

FOUCAULT, Michel. Nietzsche, la généalogie, l'histoire. In : . Dits et écrits II: 1970-1975, Paris: Gallimard, 1994b, p. 156.

FOUCAULT, Michel. Réponse à Derrida. In: . Dits et écrits II: 1970-1975. Paris: Gallimard, 1994c, p. 281-295.

GOLDSCHMIT, Marc. Jacques Derrida: une introduction. Paris: La Découverte/ Pocket, 2003.

PEETERS, Benoît. Derrida. Paris: Flammarion, 2010. 


\section{NOTAS}

${ }^{1}$ Inédita, a versão inicial deste texto foi lida em 01 de dezembro de 2011, no Seminário "Michel Foucault e os 50 anos de História da Loucura: inflexões, ressonâncias", realizado no Museu de Arte Contemporânea (MAC) de Niterói, sob curadoria de André Queiroz, numa parceria entre a Universidade Federal Fluminense (UFF) e o SESC.

${ }^{2}$ Derrida, Jacques. Cogito et l'histoire de la folie. In: L'écriture et la différance. Paris: Seuil, [1967], p. 51-97. Uma publicação brasileira recolheu parte da discussão aqui abordada, mas sem nenhum estudo crítico: Derrida, Jacques; Foucault, Michel. Três tempos sobre a história da loucura. Traduções de Pedro Leite Lopes, Vera Lúcia Ribeiro e Maria Ignes Duque-Estrada. Rio de Janeiro: Relume Dumará, 2001. O texto também comparece na edição revista e ampliada de $A$ escritura e a diferença. São Paulo: Perspectiva, 2009, p. 43-90, tradução de Pedro Leite Lopes.

${ }^{3}$ Foucault, Michel. Histoire de la folie à l'âge classique. Paris: Gallimard, 1995 [1961]. Edição brasileira: História da loucura na idade clássica. Tradução José Teixeira Coelho Netto; revisão Antonio Danesi. São Paulo: Perspectiva, 1978.

${ }^{4}$ Peeters, Benoît. Derrida. Paris: Flammarion, 2010. (Coleção Grandes Biographies.) Edição brasileira: Derrida: biografia. Tradução André Telles; revisão técnica Evando Nascimento. Rio de Janeiro: Civilização Brasileira, 2013.

${ }^{5}$ Ambas as cartas estão reproduzidas em fac-símile no volume Derrida: Cahier de L'Herne. Organizado por Marie-Louise Mallet e Ginette Michaud. Paris: l'Herne, 2004. A primeira carta se encontra nas pp. 111-112, e a segunda, nas pp. 115-116.

${ }^{6}$ Foucault, Michel. Réponse à Derrida. In: Dits et écrits II: 1970-1975. Edição estabelecida sob a direção de Daniel Defert e François Ewald. Paris: Gallimard, 1994, p. 281-295. Edição brasileira: Resposta a Derrida. In: Ditos e escritos I: problematização do sujeito: psicologia, psiquiatria e psicanálise. Tradução Vera Avellar Ribeiro. Rio de Janeiro: Forense Universitária, 1999, p. 243-257.

${ }^{7}$ Foucault, Michel. Mon corps, ce papier, ce feu. In: Dits et écrits II. Op. cit., p. 245-268.

${ }^{8}$ Derrida, Jacques. "Être juste avec Freud": l'histoire de la folie à l'âge de la psychanalyse. In: Résistances: de la psychanalyse. Paris: Galilée, 1996, p. 89-146. Edição brasileira: "Fazer justiça a Freud": a história da loucura na era da psicanálise”. In: Três tempos sobre a história da loucura. Op. cit., p. 91-151, tradução Maria Ignes Duque-Estrada. 
${ }^{9}$ Foucault, Michel. Nietzsche, la généalogie, l'histoire. In : Dits et écrits II. Op. cit., p. 156.

${ }^{10}$ É de forma sintomática que Spivak designa, em um de seus títulos, a "razão pós-colonial", Cf. Spivak, Gayatri Chakravorty. A Critique of Postcolonial Reason: Toward a History of the Vanishing Present. Cambridge, Massachusetts, London: Harvard University Press, 1999.

${ }^{11}$ Em agosto de 2004, no encerramento do "Colóquio Internacional Jacques Derrida: Pensar a Desconstrução”, por mim organizado, numa parceria da Universidade Federal de Juiz de Fora com o Consulado da França no Rio de Janeiro, teve-se a ocasião de assistir a outro denso debate, dessa vez entre Jacques Derrida e seu ex-discípulo Bernard Stiegler, em torno das "mãos do intelectual".

${ }^{12} \mathrm{Um}$ dos questionamentos mais incisivos de Derrida é quanto à periodização proposta por Foucault, em especial o conceito de "idade clássica", que acaba por repetir alguns dos estereótipos da historiografia tradicional, a despeito de toda a contribuição para a afirmação de um pensamento diferencial e não linear.

${ }^{13}$ Foucault, Michel. Histoire de la folie à l'âge classique. Op. cit., p. 47.

${ }^{14}$ Id., p. 57.

${ }^{15}$ Id., p. 58.

16 "Não quis fazer a história dessa linguagem; em vez disso, a arqueologia desse silêncio". Foucault, Michel. Préface. In: Dits et écrits I: 1954-1969. Edição estabelecida sob a direção de Daniel Defert e François Ewald. Paris: Gallimard, 1994, p. 160. Edição brasileira: Prefácio (Folie et déraison). In: Ditos e escritos I. Op. cit., p. 140-148.

${ }^{17}$ Cf. Derrida, Jacques. Cogito et l'histoire de la folie. Op. cit., p. 57 e p. 59.

${ }^{18}$ Foucault, Michel. Préface. Op. cit., p. 164.

${ }^{19}$ Derrida, Jacques. "'Être juste avec Freud"”. Op. cit.

${ }^{20}$ Descartes. Méditations métaphysiques. Cronologia, apresentação e bibliografia de Jean-Marie Beyssade e Michelle Beyssade. Paris: Gallimard, 1992, p. 71-73.

${ }^{21}$ Derrida, Jacques. Cogito et l'histoire de la folie. Op. cit., p. 86.

${ }^{22}$ Foucault, Michel. Préface. Op. cit., p. 162.

${ }^{23}$ Descartes, René. Méditations métaphysyques. Op. cit., p. 59.

${ }^{24}$ Cf. "Mon corps, ce papier, ce feu". Op. cit. Cabe ressaltar que Descartes escreveu e publicou inicialmente as Meditações em latim; depois o texto original foi traduzido em "língua vulgar" (o francês) por Louis Charles d'Albert de Luynes, com supervisão do autor. 
${ }^{25}$ Buckinx, Sébastien. Descartes entre Foucault e Derrida: Paris: L'Harmattan, 2008, p. 186.

${ }^{26}$ Joyce apud Derrida. Cogito et histoire de la folie. Op. cit., p. 51.

${ }^{27}$ Cf. Costa, Flávio Moreira da (Org.). Os melhores contos de loucura. $1^{\text {a }}$. reimpr. Rio de Janeiro: Ediouro, 2007, respectivamente p. 173-200 e p. 218-226.

${ }^{28}$ Derrida, Jacques. Cogito et histoire de la folie. Op. cit., p. 92, grifos meus.

${ }^{29}$ Goldschmit, Marc. La pensée de la folie: la controverse avec Foucault sur les rapports de l'histoire et de la philosophie. In : Jacques Derrida: une introduction. Paris: La Découverte/Pocket, 2003, p. 159-170 (p. 170).

${ }^{30}$ Outras implicações traz a fala de um sujeito que se diz louco dentro de uma narrativa em primeira pessoa, enquanto na realidade seu autor esteve internado numa clínica e passou por terapias bastante clássicas para portadores de problemas mentais. Tal foi o caso literário e existencial de Rodrigo de Souza Leão, que escreveu e publicou em vida Todos os cachorros são azuis ( $2^{\mathrm{a}}$. ed. Rio de Janeiro: 7 Letras, 2010), um dos relatos mais delirantes, cômicos e dilacerados já escritos entre nós. Ele faleceu em 2009, de ataque cardíaco, e sua obra póstuma foi publicada pela editora Record.

${ }^{31}$ Bataille, Georges. L'érotisme. Paris: Minuit, 1992, [1957].

Recebido em: 30/01/2017

Aceito em: 06/06/2017 